\title{
The Woebegone State of Companies Income Tax in Nigeria: Evidence from Widespread Tax Avoidance by Profitable Listed Companies
}

\author{
Saratu Lassa Jim-Suleiman ${ }^{1}$, Adzor Ibiamke ${ }^{2, ~ * ~}$ \\ ${ }^{1}$ Department of Accounting, University of Jos, Jos, Nigeria \\ ${ }^{2}$ Department of Accounting, Nigerian Defence Academy, Kaduna, Nigeria \\ Email address: \\ saratujimruna@gmail.com (S. L. Jim-Suleiman), aibiamke@nda.edu.ng (A. Ibiamke) \\ ${ }^{*}$ Corresponding author
}

To cite this article:

Saratu Lassa Jim-Suleiman, Adzor Ibiamke. The Woebegone State of Companies Income Tax in Nigeria: Evidence from Widespread Tax Avoidance by Profitable Listed Companies. International Journal of Finance and Banking Research. Vol. 7, No. 1, 2021, pp. 1-8. doi: $10.11648 /$ j.ijfbr.20210701.11

Received: November 8, 2020; Accepted: January 13, 2021; Published: March 10, 2021

\begin{abstract}
Profitable companies are expected to pay a 30\% companies income tax on their profits earned in Nigeria. However, many companies in Nigeria pay far less due to their application of tax avoidance strategies. This paper report how profitable companies in Nigeria are able to successfully employed the loopholes in the Nigerian tax system to significantly lower their effective tax rate over the past five years. The paper examines 68 companies that are consistently profitable in each of the five years between 2014 and 2018, excluding companies that experienced even one unprofitable year during this period. From the analysis, this paper finds that as a group, the 68 companies examined paid an effective companies income tax rate of only $16.45 \%$ over the five-year period - far less than the statutory $30 \%$ companies' income tax rate. Based on the evidence, this paper advocate for a strong alternative minimum tax that can do the job it was originally designed to do thereby bring about transparency, equity and fairness in tax payment in Nigeria. This paper adds new knowledge to the understanding of the state of tax avoidance in Nigeria. Finally, identifying firms' aggressive tax planning strategies will close the tax loopholes and boosting tax revenue in Nigeria.
\end{abstract}

Keywords: Cash Tax, Company Income Tax, Effective Tax Rate, Long-Run Tax Avoidance, Tax Planning, Tax Avoidance

\section{Introduction}

Although the statutory companies income tax rate is $30 \%$ in Nigeria, the actual tax rates also called the Effective Tax Rate (ETR hereafter) that firms in Nigeria pay is usually far less than $30 \%$, thus, making the statutory rate of tax a myth. In Nigeria, it is difficult to state exactly who the winners or losers are in corporate taxation due to lack of empirical data at the moment, however, it is believed that many companies partake in the game of tax avoidance and even industries in Nigeria. Several evidence exist to suggest the incidence of tax avoidance. For instance, the Internet giant with the motto 'don't be evil', avoids paying more than $£ 100$ m a year in UK tax despite pulling in annual revenues of more than $£ 1.25$ billion (Watts, 2009 cited in [1]). Similarly, the Ecobank Plc was asked to pay a tax of $\$ 1.6$ billion as its company income tax for year 2016 for tax avoidance in 2020 [2]. Also, in the US where the statutory tax rate is $35 \%$, Appelbaum [3] states that industry ETR varies from $2.46 \%$ to $33.77 \%$.

Tax avoidance is broadly any action taken by the firm that reduces its tax liability over a long period. It is important to note that tax avoidance does not imply that firms are engaging in anything unlawful and therefore, it is pervasive (i.e., managers or companies in theory, pursue it). In spite of the legality of tax avoidance, the practice undermines the goal of tax revenue maximisation and can also have a range of negative social and moral consequences [4]. Because tax avoidance is very prevalent among firms and even nations, it is a top concern for many nations desiring more tax revenue for accelerated growth.

This paper have several contributions to literature. First, studies abound on many aspect of tax avoidance, however, 
those that are particular about Nigeria's state of companies' income tax payment are limited, so this study fill this literature void. Furthermore, effective tax payment has received unprecedented interest in literature not only because taxation is a main source of revenue to the government but also because it significantly affects the firm's cash flows and firms' distributable income [5]. Due to the crucial nature of tax avoidance, this study provides a fascinating look on effective tax payment pattern across firms and industries in Nigeria as well as the tax avoidance strategies employed by the firms and recommends the anti-avoidance strategies that can curtail aggressive tax avoidance practices in Nigeria. This paper also contributed in alluding to the administrative capacity of tax system in Nigeria. Finally, in line with Gallemore and Labro [6] an understanding of the firms' architecture is key to understanding their tax planning practice. From the foregoing this paper is important to tax researchers, practitioners and policy formulators.

The main aim of this paper is to investigate the state of long run corporate tax avoidance of listed firms in Nigeria with a view to examine the ability of listed firms to pay low amount of cash taxes over the short and long run period. This paper is descriptive in nature. It does not test specific hypotheses about firms' propensities to avoid taxes, leaving that for future research. Rather, the paper attempts to evaluate whether firms can indeed avoid taxes over a long period of time. The paper is a key turning point in raising public ire against corporate tax evaders and ensuring that something is done to make profitable companies pay their fair share of taxes. Policymakers will use this paper to argue for a tax reform in Nigeria. Tax reform might be necessary because at the moment companies income tax payment is at a woebegone state in Nigeria. Policymakers might also find the paper helpful in determining whether particular industry or firms should have less or more tax credits.

This study document how profitable listed companies in Nigeria have been using the loopholes in taxation to avoid taxes. Using a sample of 68 companies (340 firm-years observations) from 11 industries in Nigeria, it was found that

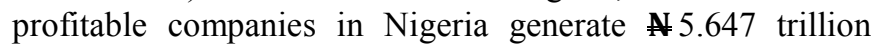
profits and paid only $\$ 0.827$ trillion as companies' income tax over the five years period translating to about $14.65 \%$. A total of 58 companies constituting $82 \%$ paid effective five-year tax rates that is less than $30 \%$ statutory companies' income tax rate in Nigeria. This evidence suggests that a sizeable subset of profitable companies in Nigeria are able to avoid corporate income taxes over long periods of time.

The rest of the paper is organized as follows: section II explains the concept of tax avoidance and the different measures of it. The section also review theoretical and empirical literature on the possible determinants of tax avoidance. Section III describes the design, sample, data and analytical techniques adopted in this paper. Section IV reports the empirical findings and other robustness tests. Finally section $\mathrm{V}$ presents the summary and concluding remarks.

\section{Related Literature}

\subsection{Concept of Tax Avoidance}

The biggest headache in tax avoidance research is the non-observability and lack of generally accepted definition of tax avoidance; according to Hanlon and Heitzman [7] the term means different things to different people. In a commonest way, tax avoidance refers to a tax choice that result to lower tax liability than would otherwise be if an alternative option is chosen [8]. It connotes the use of loopholes in the tax laws to structure transactions in a manner that reduce the amount of tax that is payable by a firm. According to Wang, et al. [9] tax avoidance can range from reduction of the corporate tax burden by legitimate use of tax rules to violation of tax laws. Buttressing further, Brown [10] states that tax avoidance involves arrangement of a transaction in order to obtain a tax advantage, benefit, or reduction in a manner unintended by the tax law. When tax avoidance is practice by an organization, cash is retained within the company that otherwise would go to the government [9]. Tax avoidance can be affront to tax administration if it violets core tax principles such as administrative efficiency, fairness, certainty, and convenience. Because the actual practice of tax avoidance is in a continuum between avoidance and evasion, tax avoidance should be given the attention that it deserves. The in continuum of tax avoidance is presented in Figure 1.

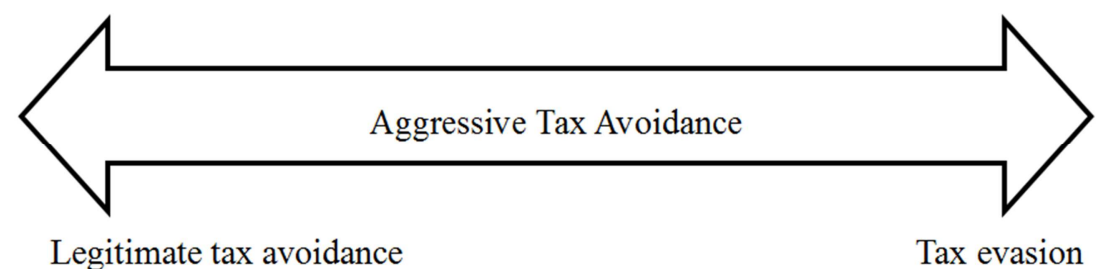

Source: Adopted from corporate tax avoidance: A literature review and research agenda by Wang et al. (2019).

Figure 1. Tax Avoidance as a continuum between legitimate tax avoidance and tax evasion.

If tax avoidance is a continuum, then there is only a thin line separating it from tax evasion which the law expressly forbidden. As an academic exercise it can be easier to distinguish between avoidance and evasion of taxes, however, in practice it is extremely difficult to separate the two concepts.
Much like art work, “... aggressiveness (beauty) is in the eye of the beholder; different people will often have different opinions about the aggressiveness of a transaction" [7]. Thus, concepts such as tax planning, tax management, tax aggressiveness, tax sheltering, and even tax evasion have been 
used to depict the conceptual meaning of tax avoidance [11]. Due to the difficulty of separating avoidance from evasion, Slemrod [12] states that "no government can announce a tax system and then rely on taxpayers' sense of duty to remit what is owed. Some dutiful people will undoubtedly pay what they owe, but many others will not. Over time the ranks of the dutiful will shrink, as they see how they are being taken advantage of by the others" (p. 1). From the forgoing, tax avoidance is used in this paper to connote all actions of the firm that result to a lower tax burden which are within the ambit of the law so long as the those actions are not forbidden in the eyes of the law as interpreted by the court.

Measurement of Corporate Tax Avoidance

Corporate tax avoidance is usually measured in two ways: one is the effective tax rates (ETR) and the other is the difference between financial reporting (book) income and taxable income. Although these two commonly used approaches exist Graham, Hanlon, Shevlin and Shroff [13] reported that from their survey of tax executives in public companies in the U.S $47 \%$ of top management values the GAAP ETR more than the cash taxes paid and another $37 \%$ values the two metrics equally. For this our concentration is on ETR measure of tax avoidance.

\subsection{Effective Tax Rate Measures}

The Effective Tax Rate is basically the ratio of tax expenses to profit before tax. Differences usually exist between ETR and the statutory rate because income is measured differently under the accounting and taxation rules. Some of these differences are temporary (e.g., depreciation) while others are permanent. Generally, ETR is calculated using equation 1.

$$
E T R=\frac{\text { Tax liability }}{\text { Profit before tax }}
$$

Any ETR below the statutory tax rate suggests tax avoidance. ETR can be computed using different measures of tax liability (e.g., total tax expense, current tax expense, cash tax expense). There are three common measures of ETR: the GAAP ETR, cash ETR and the long-run ETR.

GAAP ETR. GAAP ETR is computed as total income tax expense divided by accounting profit before tax [7], with both measures (income tax expenses and profit before taxes) available on the income statement.

$$
\text { GAAP ETR }=\frac{\text { Total income tax expenses }}{\text { Profit before tax }}
$$

The total tax expenses used in the GAAP ETR reflects all the income tax payments related to the current year's income, regardless of when the tax was, or will be, paid. Thus, GAAP ETR explains in the long-run book and taxable income differences.

Cash ETR: Cash ETR uses cash taxes paid, rather than income tax expense as the numerator.

$$
\text { Cash ETR }=\frac{\text { Cash taxes paid }}{\text { Last year profit before tax }}
$$

The cash ETR takes into account only the tax payments made in the current year. Where the denominator (profit before tax) is negative, cash ETR does not reflect effectively the tax avoidance behavior by companies. Similarly, cash taxes payments might include tax payments in the prior period without regards to the period that such tax liabilities actually arose [7].

Long-run ETR: To overcome the problems associated with annual cash ETR, Dyreng et al. [14] suggest the use of long-run cash ETR. According to Dyreng [14] long-run cash ETR is the sum of taxes paid over the years divided by the sum of profit before tax for the same period.

$$
\text { Long }- \text { Run ETR }=\frac{\sum_{t=1}^{N} \text { cash tax } \text { paid }_{i, t}}{\sum_{t=1}^{N}{\text { profit before } \text { tax }_{i, t}}}
$$

Although the long run ETR does not completely eliminate the problems with annual ETR, it reduces the effects of temporary differences in measuring tax avoidance behavior when the Cash ETR is compared to the statutory rate.

Book-Tax Differences: Book-tax differences (BTD) is simply the differences between accounting profit before tax and taxable income. Since taxable income obtainable from tax returns is usually not available to the public domain, the measurement of BTD begins with first an estimation of taxable income (estimated as current income tax expense divided by the statutory tax rate) [15].

$$
\text { TotalBTD }=\text { profit before tax }-\frac{\text { income tax expenses }}{\text { Statutory rate of tax }}
$$

Extant literature states that BTD is partially related to tax avoidance, however, BTD is affected by earnings management as well thus making BTD a noisy measure of tax avoidance [16].

Theoretical and Empirical Review

Two lines of research are related to this paper. The first pertains to studies investigating variation in ETR. The second interrogates the causes and consequences of book-tax differences. However, this paper limit itself to the former; the later aspects is considered as a follow-up study to unravel all the causes and consequences of tax avoidance in Nigeria in order to chant the way forward for regulative action.

Research on the variation in ETR date back to over three decades (see [17, 9] for summaries). Zimmerman [18] reports that firm size is positively associated with their ETR consistent with the political cost hypothesis. Using the political cost theory, Watts and Zimmerman [19] explain that the higher visibility of larger and more successful firms causes them to be victims of greater regulatory actions and wealth transfers. Since taxes are aspect of political cost, the theory hypothesized that larger firms have more ETR than smaller firms. Gupta and Newberry [20] tested for the political theory and failed to arrive at the results that size influences ETR.

Another factor identified in literature as a determinant of tax avoidance is thin capitalization. A thinly capitalized entity is one that employs more debt than equity (highly geared) in its capital structure. A common decimal in most "national tax systems is that interest expenses related to debt are tax deductible whereas the opportunity cost of equity is not [21]. 
In Nigeria, thin capitalization rules based on the Finance Act 2019 restricts interest deductibility to $30 \%$ of earnings before interest, taxes, depreciation, and amortization (EBITDA). Excess interest can be carried forward for up to 5 years. Research on thin capitalization are mainly based on the trade-off theory which postulates that a firm's choice of debt versus equity is a trade-off, where firms weigh the benefits of debt against the costs. Trade-off theory has several implications to empirical investigations. First, one-to-one relationship between taxes and debt is assumed. Increase in company income tax rate might result more debts to enjoy tax saving, but cost factors like bankruptcy cost might reduce the tax advantage. Other non-tax factors may also dampen the tax incentive and then makes the relationship less direct than as anticipated in trade-off theory. Research by Slemrod [22] and Taylor and Richardson [23] find that highly leveraged firms in the US and Australia respectively have lower effective tax rates (ETRs) because of the use of debt deductions to reduce taxable income. In Germany, Overesch and Wamser [24] suggest that tax planning via internal finance is effectively limited by thin-capitalization rules. Møen, Schindler, Schjelderup and Bakke [25] also found that internal and external debt shifting are almost about equally important to German multinationals.

The final aspect of determinants of variation in effect tax payment is the executives' personal characteristics. The effect of top executives is expected to influence tax avoidance practice because these executives set the "tone at the top" in the organization. The impetus of this arguments is the upper echelons theory which suggests that organizational outcomes (strategic choices) are partially a reflection of personal top management level background characteristics [26]. Dyreng, Hanlon and Maydey [27] investigate and track movements in 908 executives (including CEOs and CFOs) of U.S firms and found that top executive background characteristics have incremental effects on their tax avoidance practice that cannot be explained by the firms' attributes. They then concluded that executive background feature is an important determinant in firms' tax avoidance. More recent study by Hjelström, Kallunki, Nilsson and Tylaite [28] in Sweden also confirm that CEOs' and CFOs' personal tax behavior is related corporate tax avoidance. Law and Mills [29] argue that managers with military experience engage in less tax avoidance because aggressive tax avoidance may violate common values.

\section{Research Design}

Descriptive research approach is adopted in this paper since it is most appropriate in solving the study problem. This kind of design is used to obtain information concerning the current status of the phenomena and to describe "what exists" with respect to variables or conditions in a situation [30].

The study relies on a hand-collected data from the annual reports for all the available listed companies in Nigeria from 2014 to 2018 . These five years period was selected because they represent the most recent years for which financial statement data are currently available. This paper also cover only five years in order to maximize the sample size. To qualify for sampling in this paper each company is required to have annual financial reports publicly available at the Nigerian Stock Exchange website, and must also have five years of consecutive non-missing income tax expense, cash taxes paid, and operating profit before tax. Thus, we begin with an initial sample of 163 listed companies found on the Nigerian Stock Exchange Website as at $1^{\text {st }}$ April, 2020. From the initial sample, 40 companies were dropped because they failed to publish their annual reported on either theirs or Nigerian Stock Exchange website for the five consecutive years for reasons such as been newly listed, merged or taken-over or missing regulatory filing. Finally, the computation of ETR requires that the denominator value should be positive since such observations do not reflect actual tax liability in a year [18, 31]. Thus, another 55 companies that do not report profit throughout the five years are eliminated given rise to a working sample of 68 companies.

The tax avoidance is measured using annual GAAP ETR, cash ETR and long-run cash ETR proposed by Dyreng et al. [14], the computation of these measures is as shown in equation (2), (3) and (4) respectively. GAAP ETR equals income tax expense divided by profit before tax minus special items. Cash ETR is the cash effective tax rate, defined as income taxes paid divided by profit before tax minus special items following Dyreng et al. [27]. Descriptive statistics and graphs were used to analyse the data extracted from the annual reports of the 68 sampled companies. Finally, Mann-Whitney $\mathrm{Z}$ test was used to check whether some firm variables are capable of explaining the difference between low and high long-run ETR.

\section{Analyses and Results}

\subsection{The Distributional Characteristics of Effective Tax Rate}

Table 1 report the distributional characteristics of long-run GAAP ETR and Cash ETR. The table summarises what the 68 companies paid (or didn't pay) in effective companies' income tax on their operating profit before taxes in Nigeria.

As a group, the 68 companies examined in this paper paid an effective income tax rate of just $14.65 \%$ over the five-year period - far less than the statutory $30 \%$ statutory tax rate. The total operating profit generated by the 68 profitable companies in Nigeria over the five years (2014-2018) period is about $\$ 5.647$ trillion and paid only $\$ 0.827$ trillion as company income tax. 58 companies constituting $82 \%$ paid effective five-year tax rates that is less than $30 \%$. Only 11 companies (about $18 \%$ of the sampled companies) paid effective five year tax rates of more than $30 \%$. Considering the results on annual basis Panel A in Table 1 revealed that in 198 firm-years (i.e., for over one-half of the sample years), companies in Nigeria paid a low effective taxes rate; in another 92 firm-years (which is $27 \%$ of sample observations) the companies paid medium effective tax rate, and finally, for about 50 firm-years (which is $15 \%$ of sample years), companies in Nigeria paid effectively high tax rates. The classification of tax rates into "low" 
"medium" and "high" follows Dyreng et al. [14]. According to their study, the classification of firms as "low" tax rate firms is when cash ETR is less than or equal to $20 \%$, and high "high" if cash ETR is greater than $40 \%$. Tax rate in between $20-40 \%$ is classified as "medium" tax rates.

Table 1. Distributional Characteristics of long-run GAAP and Cash ETRs.

Panel A: Number and Percentage of Companies with high or low cash ETR

\begin{tabular}{|c|c|c|c|c|c|}
\hline \multicolumn{6}{|c|}{ Cash ETR } \\
\hline \multicolumn{4}{|c|}{ Number and $\%$ of companies that pay less than $30 \%$ CIT rate } & \multicolumn{2}{|l|}{$57(84 \%)$} \\
\hline \multicolumn{4}{|c|}{ Number and $\%$ of companies that pay more than $30 \%$ CIT rate } & \multicolumn{2}{|l|}{$11(16 \%)$} \\
\hline \multicolumn{4}{|c|}{ Number and $\%$ of firm year observations with low CIT rate } & \multicolumn{2}{|l|}{$198(58 \%)$} \\
\hline \multicolumn{4}{|c|}{ Number and $\%$ of firm year observations with medium CIT rate } & \multicolumn{2}{|l|}{$92(27 \%)$} \\
\hline \multicolumn{4}{|c|}{ Number and $\%$ of firm year observations with high CIT rate } & \multicolumn{2}{|l|}{$50(15 \%)$} \\
\hline \multicolumn{6}{|c|}{ Panel B: Descriptive Statistics } \\
\hline & GAAP ETR & Cash ETR & Profit N'million & Tax Expenses N' million & Cash tax Paid N' million \\
\hline Total & $16.62 \%$ & $14.65 \%$ & $5,647,495$ & 938,653 & 827,348 \\
\hline Mean & $24.60 \%$ & $20.24 \%$ & 83,051 & 13,804 & 12,163 \\
\hline Median & $25.93 \%$ & $17.24 \%$ & 9,565 & 1,554 & 1,298 \\
\hline Std Dev & $11.36 \%$ & $13.76 \%$ & 700,196 & 114,903 & 101,795 \\
\hline Max & $60.07 \%$ & $69.65 \%$ & $1,144,308$ & 132,453 & 138,896 \\
\hline Min & $1.30 \%$ & $0.00 \%$ & 20 & 5,484 & 0 \\
\hline
\end{tabular}

Source: Authors compilation (2020)

The Panel B in Table 1 reveals that there is wide variation around the mean and median tax expenses and also payment. The mean (standard deviation) profit, tax expenses and cash tax payment are $\$ 83.051$ ( $S . D=700.196)$ million, $\$ 13.415$ (S. $\quad D=114.903$ ) million, and $\$ 12.094$ ( $S . \quad D=101.795)$ million respectively. This represent the mean GAAP ETR of $24.60 \%$ and Cash ETR of 20.24\%. However, considering the high variation in profit and tax figures across companies due to their sizes, median was employed instead as a better measure of central tendency. Using the median, we conclude that over half of the companies generate up to $\$ 9.564$ million as profit, report tax expenses of $\$ 1.507$ million and actually paid income tax of $\$ 1.298$ million representing median GAAP ETR of $25.93 \%$ or Cash ETR of $17.02 \%$ only. The minimum GAAP ETR and Cash ETR are $1.30 \%$ and $0 \%$ respectively.

Figure 2 presents histograms of CASH ETRs over one and five-year average per sample firm. The samples are classified into "high" "medium" and "low" tax rates using [14] methodology. The sample from which the observations was obtained for each panel is the 68 firms that have consecutively five years profit. In the Panel A of Figure 2 it could be observed that a the 68 firms had paid low annual tax rates for 198 out of 340 total firm years. When the data was averaged by firms over each of the five years, we found that 44 firms out of 68 sampled companies paid low tax rates as presented in Panel B in Figure 2. Since both annual cash ETR and five years average ETR indicates low effective tax payment, using either the annual cash ETR or long-run ETR would result in high accuracy rate in the classification of tax avoiders from non-tax avoiders. Only about $98(27 \%)$ of the sample years has cash ETR between $20 \%$ and $40 \%$. Using the five years average only 17 companies out of the 68 representing $25 \%$ have medium cash ETR. Lastly, 50 sampled firm years have high cash ETR approximately $15 \%$ of the sample years. With a five-year average measurement, slightly more than $10 \%$ of the sample companies has cash ETRs between above $40 \%$. The figures in Panel A and B in Figure 2 indicate that it is possible for companies to have low tax rate in a year and continues with that as one lengthens the time period.

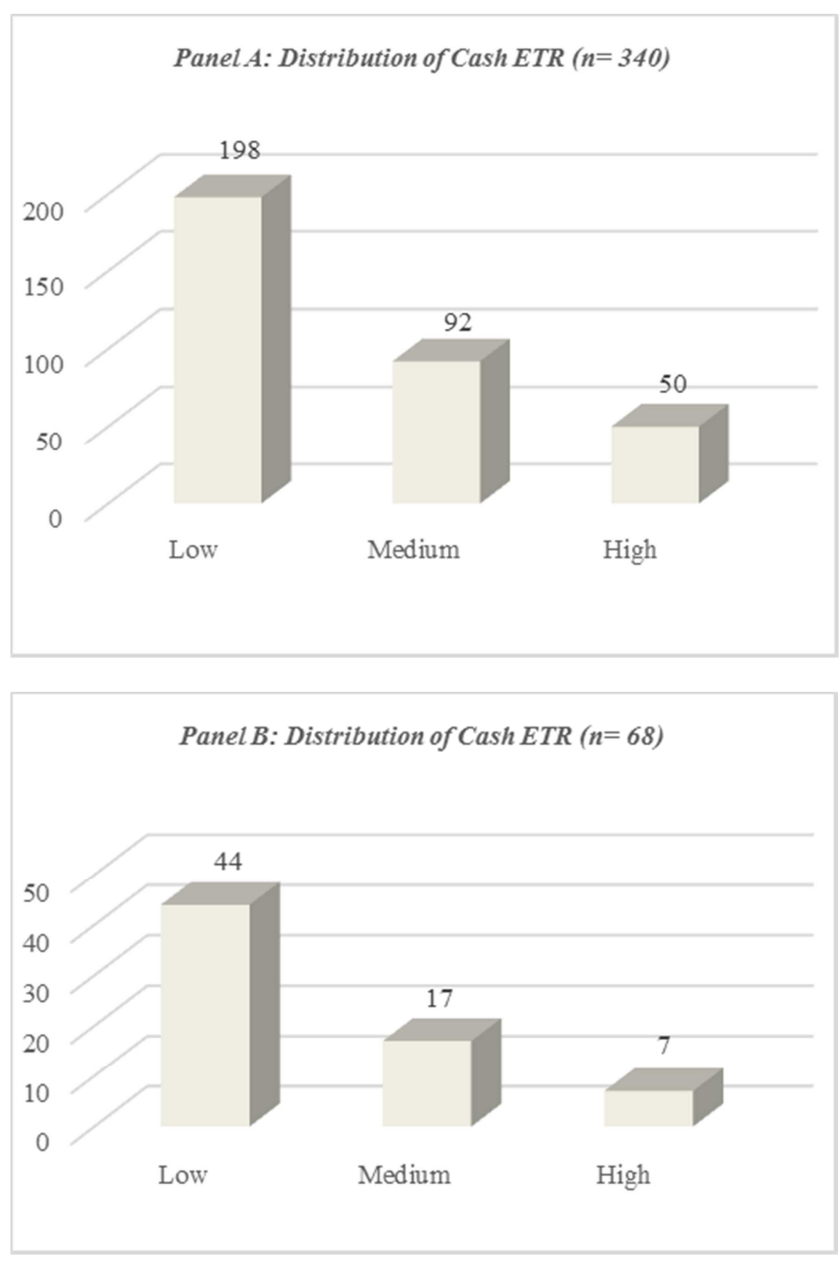

Source: Authors compilation (2020).

Figure 2. Effective Rate of Company Income Tax Payment in Nigeria. 


\subsection{Cash Effective Tax Rates across Industries}

To examine whether the variation in cash ETR is a function of industry membership, this paper also measure cash ETR by industry and present the result in Table 2 .

Table 2. Effective Corporate Tax Rates for 68 Companies by Industry, 2014-18.

\begin{tabular}{|c|c|c|c|c|c|}
\hline \multirow{2}{*}{ Sector } & \multicolumn{2}{|l|}{ Total } & \multicolumn{2}{|l|}{ Average } & \multirow{2}{*}{ Cash ETR } \\
\hline & Profits $=$ N'000 & Tax paid N'000 & Profit N'000 & Tax paid N'000 & \\
\hline Industrial goods & $1,184,766,942$ & $27,538,242$ & $47,390,678$ & $1,101,530$ & $2.32 \%$ \\
\hline Construction/real estate & 86,756 & 2,172 & 17,351 & 434 & $2.50 \%$ \\
\hline Agriculture & $86,407,981$ & $10,763,584$ & $8,640,798$ & $1,076,358$ & $12.46 \%$ \\
\hline Natural resources & $2,121,858$ & 282,462 & 212,186 & 28,246 & $13.31 \%$ \\
\hline Financial services & $3,437,052,751$ & $541,712,010$ & $25,459,650$ & $4,012,682$ & $15.76 \%$ \\
\hline Services & $37,106,058$ & $6,443,228$ & $1,060,173$ & 184,092 & $17.36 \%$ \\
\hline $\mathrm{ICT}$ & $2,546,185$ & 561,876 & 169,746 & 37,458 & $22.07 \%$ \\
\hline Consumer goods & $689,413,496$ & $179,182,383$ & $15,320,300$ & $3,981,831$ & $25.99 \%$ \\
\hline Conglomerates & $39,730,537$ & $10,752,441$ & $7,946,107$ & $2,150,488$ & $27.06 \%$ \\
\hline Oil and gas & $154,822,587$ & $44,226,516$ & $4,423,502$ & $1,263,615$ & $28.57 \%$ \\
\hline Healthcare & $13,439,696$ & $5,630,633$ & 671,985 & 281,532 & $41.90 \%$ \\
\hline All Industries & $5,647,494,847$ & $827,348,060$ & $16,610,279$ & $2,432,634$ & $14.65 \%$ \\
\hline
\end{tabular}

Source: Authors compilation (2020)

We follow the 11 industry classification system by the Nigerian Stock Exchange. The effective tax rates in our study varied widely by industry. Over the $2014-18$ period, effective industry tax rates (for our 68 companies) ranged from a low of $2.32 \%$ to a high of $41.90 \%$. Industrial goods companies enjoyed the lowest effective company tax rate over the five years period, paying a tax rate of only $2.32 \%$. Beside the health care industry, all other industries pay less than $30 \%$ statutory company income tax rate over the entire 2014-18 period included: construction/real estate $(2.50 \%)$, agriculture $(12.46 \%)$, natural resources $(13.31 \%)$, financial services $(15.76 \%)$, services $(17.36 \%)$, ICT $(22.07 \%)$, oil and gas $(25.67 \%)$, consumer goods $(25.99 \%)$ and conglomerates $(27.06 \%)$. These results were largely driven by the ability of these companies to claim accelerated depreciation tax breaks on their capital investments.

The firm with the least ETR comes from the industrial sector. The industrial goods industry firm \#5 report various reasons for tax savings in the tax reconciliation statement including previous years over provision for tax followed by income exempted from tax and deferred taxes. Generally, tax law permit companies to write off their capital investment faster than assets actually wear out. This "accelerated depreciation" is technically a tax deferral, but so long as a company continues to invest, the tax deferral tends to be indefinite. Although differences in annual capital allowances and depreciation rates causes tax savings, limited financial reporting makes it hard to calculate exactly how much of the tax breaks one can identify as depreciation-related tax savings.

In addition to accelerated depreciation, the deductibility of interest expenses can give rise to tax savings. For instance, a company might borrow money to finance Property Plant and Equipment (PPE), deduct the interest expenses on the debt and quickly deduct the cost of the PPE using the prevailing capital allowances. The total deductions can then make the investments more profitable after-tax than before-tax.

The company with least GAAP ETR from health care industry is company \#2. Specifically, pharmaceutical companies usually engaged in research and development which is tax deductible. There have also been assertions that pharmaceutical companies are adept at shifting income to low-tax jurisdictions by transferring intellectual property (e.g., patents) there and charging royalties to affiliates in high tax countries [32]. From the annual reports, company \#2 in the health care industry reports that its tax saving is basically due to two reasons, first, the tax exempt income which is $120 \%$ of its pre-tax profit and second, the deferred taxation which is about $110 \%$ of pre-tax profit.

Financial Institution Firms \#15, \#20 \& \#25, both insurance companies, all have investments that generate large amounts of tax-exempt income (specifically, income from bonds and treasury bills ${ }^{1}$ ) with only a small amount of expenses added back as disallowable for tax, thus, lowering their ETR.

\subsection{Descriptive Data Tax Avoiders and High Tax Payers}

Companies have access to a variety of tax-saving factors and chooses a set of these factors that determine its effective tax rate. To better understand why certain companies or even industries pay low effective companies income tax, this paper divide companies into two groups. Seven (7) companies with more than $40 \%$ ETR are classified as high tax paying companies, while nineteen (19) companies with both long-run GAAP ETR and cash ETR are classified as low effective tax paying companies. Two low tax paying companies were dropped because they have no tax reconciliation statements in their financial reports thus, leaving seventeen (17) low tax paying companies. Table 3 presents some basic descriptive data about characteristics of the firms in the sample. The sample is divided into two group - firms with less than $20 \%$ long-run ETR as low and firms with more than $40 \%$ long-run ETR as high.

Results from Table 3 reveal that the long-run tax avoiders have higher operating profit margin (operating profit before tax divided by revenue) than non-tax avoiders. A Mann-Whitney test indicated that this difference was

1 Income from bonds and treasury bills was exempted for tax for 10 years according to Companies' Income Tax order 2011. 
statistically significant $z=5.263, p<.001$. The statistical significance value shows that if the study is replicated 1000 times, the finding will be always correct. Return on Assets is significantly positive which indicates that more profitable firms have higher GAAP ETRs. High income exempted from tax relative to expenses disallowable for tax purpose might account for the reason why firms with high operating profit margins pay low ETR. For the low ETR group the income exempted from tax covers disallowable expenses over 55 times whereas the average for high ETR group is just about 1.09 times. Tax avoiders tend to invest in securities that have tax exempted income such as bonds and treasury bills than firms with high ETR.

Table 3. Descriptive Data of Long-Run ETR by Tax Group.

\begin{tabular}{|c|c|c|c|c|c|c|c|}
\hline \multirow[t]{2}{*}{ Category } & \multicolumn{2}{|c|}{ Low ETR } & \multicolumn{2}{|c|}{ High ETR } & \multirow{2}{*}{$\begin{array}{l}\text { Difference } \\
\text { Low-High }\end{array}$} & \multicolumn{2}{|c|}{ (Mann-Whitney) } \\
\hline & $\mathbf{N}$ & Mean & $\mathbf{N}$ & Mean & & $z$ test & prob $>/ \mathbf{z} /$ \\
\hline Operating Margin & 85 & 0.2211 & 35 & 0.0665 & 0.1546 & 5.2630 & 0.0000 \\
\hline Leverage & 85 & 0.6023 & 35 & 0.5231 & 0.0792 & 2.0238 & 0.0238 \\
\hline Size & 85 & 11.1281 & 35 & 10.2652 & 0.8629 & 3.5020 & 0.0005 \\
\hline Disallowable expenses to income exempted from tax & 55 & 55.2379 & 17 & 1.0933 & 54.1446 & 4.0510 & 0.0001 \\
\hline$R \& D$ & 2 & 0.0069 & 5 & 0.0093 & -0.0024 & 1.1620 & 0.2453 \\
\hline Advertising & 64 & 3.4591 & 19 & 0.0223 & 3.4368 & -0.0650 & 0.9481 \\
\hline Capital Intensity & 42 & 0.4876 & 31 & 0.0326 & 0.4550 & -0.1340 & 0.8935 \\
\hline Intangible & 70 & 0.0947 & 26 & 0.0391 & 0.0556 & -1.4590 & 0.1445 \\
\hline
\end{tabular}

Source: Authors compilation (2020).

The long-run tax avoiders are also more highly geared. This result collaborate with findings of Slemrod [22] in the US and Taylor and Richardson [23] in Australia who both found that highly leveraged firms have lower ETR due to debt interest deductions. The result also support the previous theoretical postulations that thinly capitalised entities will enjoy lower effective tax payment. Tax avoidance group have average finance cost to total revenue of 4.577 as against 0.036 in the high ETR group.

Similar to Dyreng et al. [14], this paper finds that smaller firms pay higher ETR than larger firms. This finding contrast the political cost theory proposition. In Nigeria the argument that larger firms have greater regulatory action is not tenable. Rather size gives companies tax negotiation advantage and financial capability to hire tax consultants who might help them to plan their taxes by carefully studying and exploring the many loopholes in Nigerian tax system.

Finally, factors such as $R \& D$, capital intensity, intangible assets, advertising, and training cost do not significantly differ between high and low ETR Companies. While the univariate results gives an insight on firms' characteristics that account for low and high ETR in Nigeria, this paper suggests a detailed analysis of causes of short and long-term ETR in Nigeria as a future research agenda.

\section{Conclusions}

For a longtime there has been several studies on tax avoidance, however the state of tax avoidance and causes of it in Nigeria is limited. This paper fill this literature void by unravelling how profitable companies in Nigeria are able to successfully employ the loopholes in the Nigerian tax system to significantly lower their effective tax rate over the years. Findings indicate that the 68 profitable companies in Nigeria that are examined in this paper paid an effective companies income tax rate of just $16.45 \%$ over the five-year period - far less than the statutory $30 \%$ companies' income tax rate.
Overall, the analysis revealed many avenues for tax reduction both in the short and long run. Some of the reasons are firm idiosyncratic while others are industry generic. A more detail examination of the causes of ETR is a fertile avenue for future research.

Based on the findings, this paper advocate for a strong alternative minimum tax that can do the job it was originally designed to do thereby bring about transparency, equity and fairness in tax payment in Nigeria. The paper also recommends that more complete and transparent geography-specific public disclosure of corporate income and tax payments than it is currently mandated. This paper adds new knowledge to the understanding of the state of tax avoidance in Nigeria. Finally, identifying firms' aggressive tax planning strategies will close the tax loopholes and boosting tax revenue in Nigeria.

\section{References}

[1] Fuchs, C. (2018). The online advertising tax as the foundation of a public service internet: A CAMRI extended policy report. University of Westminster Press.

[2] Adeboyega, A. (June, 2020). Tax evasion: Tribunal orders Ecobank to pay N1.6 billion to FIRS - official. Premium Times Newspaper of 18 June, 2020. Retrieved from https://www.premiumtimesng.com/business/379291-tax-evasi on-tribunal-orders-ecobank-to-pay-n1-6-billion-to-firs-official .html

[3] Appelbaum, B. (January, 2011). Corporate taxes: More winners and losers. The New York Times, January 27. Retrieved from https://economix.blogs.nytimes.com/2011/01/27/corporate-tax es-more-winners-and-losers/ on 02/21/2020

[4] Obedina, D. A. (2015). Fighting aggressive tax avoidance in Nigeria: An agenda for reform. Ife Juris Review, 4 (1), 38-57. 
[5] Liu, X. \& Cao, (2007). Determinants of corporate effective tax rates: Evidence from listed companies in China. The Chinese Economy, 40 (6), 49-67.

[6] Gallemore, J. \& Labro, E. (2015). The importance of the internal information environment for tax avoidance. Journal of Accounting and Economics, 60 (1), 149-167.

[7] Hanlon, M. \& Heitzman, S. (2010). A review of tax research. Journal of Accounting and Economics, 50 (2-3), 127-178. doi: 10.1016/j.jacceco.2010.09.002.

[8] Oats, L. \& Tuck, P. (2019). Corporate tax avoidance: Is tax transparency the solution? Accounting and Business Research, 49 (5), 565-583, DOI: 10.1080/00014788.2019.1611726.

[9] Wang, F., Xu, S., Sun, J. \& Cullinan, C. P. (2019). Corporate tax avoidance: A literature review and research agenda. Journal of Economic Surveys. doi: 10.1111/joes.12347.

[10] Brown, K. B. (2012). Comparative regulation of corporate tax avoidance: An overview. In K. B Brown (ed.), A comparative look at regulation of corporate tax avoidance, Ius Gentium: Comparative perspectives on law and justice 12 (pp. 1-24). Springer Science+Business Media B. V. DOI 10.1007/978-94-007-2342-9_1.

[11] Aronmwa, E. J. \& Okafor, C. (2019). Corporate tax avoidance: Review of measures and prospects. International Journal of Accounting \& Finance, 8 (2), 21-42.

[12] Slemrod, J. (2007). Cheating ourselves: The economics of tax evasion. Journal of Economic Perspectives, 21 (1), 25-48.

[13] Graham, J. R., Hanlon, M., Shevlin, T. \& Shroff, N. (2014). Incentives for tax planning and avoidance: Evidence from the field. The Accounting Review, 89 (3), 991-1023. doi: $10.2308 /$ accr-50678.

[14] Dyreng, S. D., Hanlon, M. \& Maydew, E. L. (2008). Long-run corporate tax avoidance. The Accounting Review, 83 (1), 6182 .

[15] Lee, B. B., Dobiyanski, A. \& Minton, S. (2015). Theories and empirical proxies for corporate tax avoidance. Journal of Applied Business and Economics, 17 (3), 21-34.

[16] Graham, J. R., Raedy, J. S. \& Shackelford, D. (2012). Research in accounting for income taxes. Journal of Accounting and Economics 53 (1-2), 412-434.

[17] Callihan, D. (1994). Corporate effective tax rates: A synthesis of the literature. Journal of Accounting Literature 13, 1-43.

[18] Zimmerman, J. (1983). Taxes and firm size. Journal of Accounting and Economics 5, 119-149.

[19] Watts, R. \& Zimmerman, J. (1986). Towards a positive theory of accounting. Englewood Cliffs, NJ: Prentice-Hall.
[20] Gupta, S. \& Newberry, K. (1997). Determinants of the variability in corporate effective tax rates: Evidence from longitudinal data. Journal of Accounting and Public Policy, 16, $1-34$.

[21] Schjelderup, G. (2016). The tax sensitivity of debt in multinationals: A review. International Journal of the Economics of Business, 23 (1), 109-121. DOI: 10.1080/13571516.2015.1115661.

[22] Slemrod, J. (2001). A general model of the behavior response to taxation. International Tax and Public Finance, 8 (2), 119-128.

[23] Taylor, G. \& Richardson, G. (2013). The determinants of thinly capitalized tax avoidance structures: Evidence from Australian firms. Journal of International Accounting, Auditing and Taxation 22, 12-25.

[24] Overesch, M. \& Wamser, G. (2010). Corporate tax planning and thin-capitalization rules: Evidence from a quasi-experiment, Applied Economics, 42 (5), 563-573, DOI: 10.1080/00036840701704477.

[25] Møen, J., Schindler, D., Schjelderup, G. \& Bakke, J. T. (2019). International debt shifting: The value-maximizing mix of internal and external debt. International Journal of the Economics of Business, DOI: 10.1080/13571516.2019.1599189.

[26] Hambrick, D. C., \& Mason, P. A. (1984). Upper echelons: The organization as a reflection of its top managers. The Academy of Management Review, 9 (2), 193. doi: 10.2307/258434.

[27] Dyreng, S. D., Hanlon, M. \& Maydew, E. L. (2010). The effects of executives on corporate tax avoidance. The Accounting Review, 85 (4), 1163-1189.

[28] Hjelström, T., Kallunki, J.-P., Nilsson, H. \& Tylaite, M. (2019). Executives' personal tax behavior and corporate tax avoidance consistency. European Accounting Review, 1-28. doi: $10.1080 / 09638180.2019 .1642222$.

[29] Law, K. K., \& Mills, L. F. (2017). Military experience and corporate tax avoidance. Review of Accounting Studies, 22 (1), 141-184.

[30] Anastas, J. W. (1999). Research design for social work and the human services. Columbia University Press.

[31] Richardson, G. \& Lanis, R. (2007). Determinants of the variability in corporate effective tax rates and tax reform: Evidence from Australia. Journal of Accounting and Public Policy, 26 689-704.

[32] Almond, J. \& Sullivan, M. (2004). Drug firms park increasing share of profits in low-tax countries. Tax Notes (September 20), 1336-1343. 